\title{
Citrus Diseases Exotic to Florida: Citrus Leprosis ${ }^{1}$
}

\author{
O. Batuman, A. Levy, P. Sieburth, A. M. Paolillo, K.-R. Chung, and R. H. Brlansky²
}

Citrus is susceptible to a large number of diseases caused by fungal, bacterial, and viral plant pathogens. Economic losses due to plant diseases can be severe, but fortunately, not all pathogens attacking citrus are found in Florida. The major citrus diseases currently found in Florida that cause the most economic damage are huanglongbing, citrus canker, and postbloom fruit drop. Other economically important diseases present in Florida include Alternaria brown spot, blight, greasy spot, melanose, Phytophthorainduced diseases (foot and root rot, brown rot), citrus black spot, scab, and tristeza. Any exotic disease, if introduced, may further increase production costs and decrease profitability for Florida growers. This document is one in a series designed to provide important information on the causal agent, symptoms, and transmission of exotic citrus diseases. Disseminating the information about the diseases to the citrus industry may prevent their introduction and spread in Florida. This document will focus on the exotic viral disease citrus leprosis.

\section{What is citrus leprosis?}

Citrus leprosis is a nonsystemic viral disease that causes chlorotic lesions on citrus leaves, fruit, twigs, and branches. The causal virus agents of citrus leprosis consist of a number of viruses with remarkably similar biology. These viruses (12 viruses in three genera) are grouped together by their similar disease symptoms and genomic characteristics, and by the cellular location of the virus (i.e., cytoplasmic type or nuclear type; Figure 1). These viruses are transmitted by species of Brevipalpus mites (also known as flat mites or false spider mites; Figure 2). The disease is found in Mexico, Brazil, Colombia, Venezuela, Panama, Costa Rica, and other countries in South and Central America. Citrus leprosis is currently a highly important citrus disease in these areas due to the yield loss resulting from unmarketable fruit. Citrus leprosis was once a serious disease of citrus in Florida, when it was found in the early 1900s. By the 1960s citrus leprosis was only found in isolated areas on the east coast, and it eventually disappeared from Florida. The reason for its disappearance is unknown. However, it is believed to have been a result of both the increased use of sulfur to control mite vectors and a freeze that took place in 1962, which severely reduced the mite vector populations and the leprosis inoculum. A great deal of uncertainty exists about the epidemiology of citrus leprosis and its potential to reappear in Florida.

\section{Which plants are affected by citrus leprosis?}

Citrus leprosis primarily affects oranges, but grapefruit, mandarin, lime, and sweet lime can also be affected. There is no known systemic host for the leprosis viruses; however, a number of noncitrus plants show local lesions upon infection as well. Leprosis viruses can be experimentally transmitted to some herbaceous plants (e.g., common bean, purslane, Benghal dayflower, globe amaranth, ivy, zinnia,

1. This document is PP148, one of a series of the Plant Pathology Department, UF/IFAS Extension. Original publication date April 2006. Revised October 2020. Visit the EDIS website at https://edis.ifas.ufl.edu for the currently supported version of this publication.

2. O. Batuman, assistant professor, UF/IFAS Southwest Research and Education Center; A. Levy, assistant professor, UF/IFAS Citrus REC; P. Sieburth, biological scientist III (retired), Bureau of Citrus Budwood Registration, DPI-FDACS; A. M. Paolillo, citrus Extension agent, UF/IFAS Extension DeSoto County; K.-R. Chung, former associate professor; and R. H. Brlansky, professor emeritus, Plant Pathology Department, UF/IFAS Citrus REC; UF/IFAS Extension, Gainesville, FL 32611.

The Institute of Food and Agricultural Sciences (IFAS) is an Equal Opportunity Institution authorized to provide research, educational information and other services

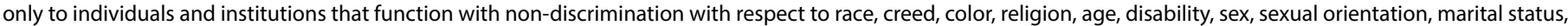

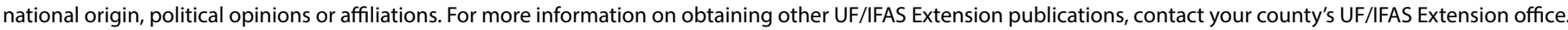
U.S. Department of Agriculture, UF/IFAS Extension Service, University of Florida, IFAS, Florida A \& M University Cooperative Extension Program, and Boards of County Commissioners Cooperating. Nick T. Place, dean for UF/IFAS Extension. 
and watercress), producing local lesions. Citrus leprosis symptoms have been reported on citrus seedlings fed on by Bevipalpus mites collected from Spanish needle plants (Bidens alba), but its status as a weed host has not been determined.
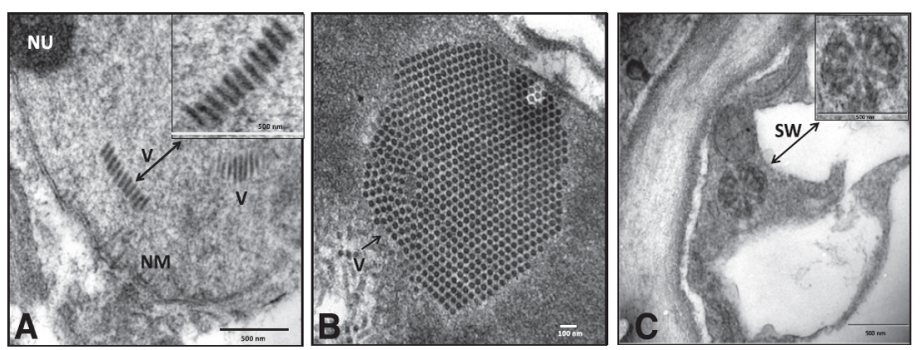

Figure 1. Transmission electron micrographs of citrus leprosis virusinfected cells. A: Nucleus containing bullet-shaped nuclear (N-type) virus particles. The boxed area is an enlarged view of virus particles. NM and NU are the nuclear membrane and nucleolus, respectively. B: Transverse section of a typical lesion from a citrus-leprosis-diseased mandarin leaf tissue showing the stacks of virus particles (V). C: Arrangement of rod-shaped virus particles (C-type) showing the spoke wheel (SW)-like configurations in the cytoplasm of the virus infected leaf. The boxed area is an enlarged view of SW arrangement.

Credits: Used with permission from Roy et al. (2015)

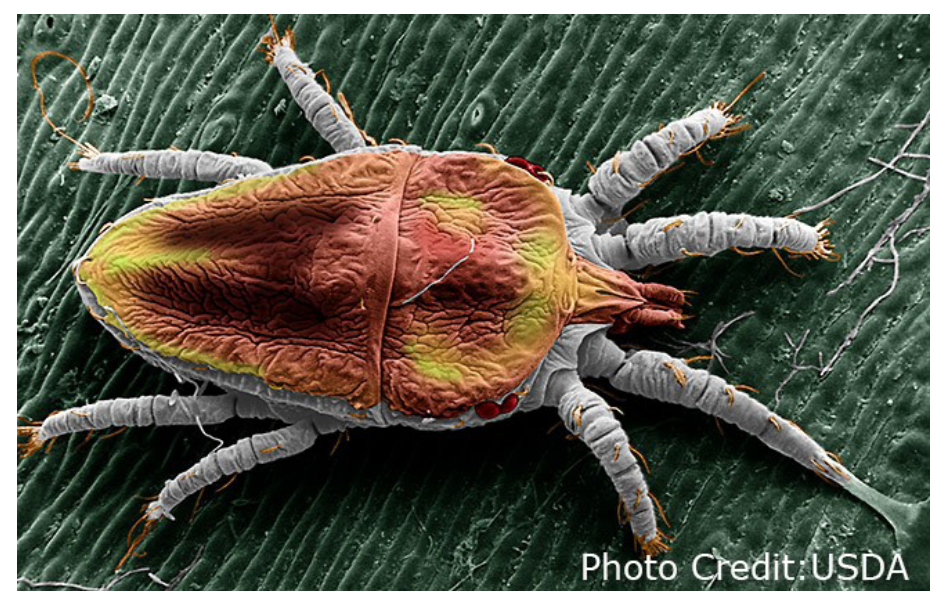

Figure 2. The Brevipalpus yothersi flat mite transmits citrus leprosis disease.

Credits: USDA

\section{What are the typical symptoms caused by citrus leprosis?}

Citrus trees with citrus leprosis have necrotic (dead) lesions, often with a yellow halo on the leaf and fruit, and necrosis on bark at the feeding sites of the Brevipalpus mites. The fruit lesions are usually chlorotic (pale colored) at first and then may become necrotic in the center with a distinct yellow halo (Figures 3-4). There may be concentric patterns present in the form of rings and gum impregnation in old lesions, giving a brown appearance. Stem lesions start as shallow chlorotic concentric rings and may coalesce as they increase in size. The lesions over time become corky and produce bark scaling, and when severe, they result in premature fruit drop, leaf abscission, and twig dieback (Figures 5-6). Leaf lesions are smooth and can vary based on the type of leprosis present ( $\mathrm{C}$ or $\mathrm{N}$ type), but they generally start as chlorotic circular spots, then become brown in color (Figure 7). As they age, the centers can become necrotic (Figure 8). The leaf lesions occur on the upper and undersides of the leaves. The lesions on the upper sides of the leaves are more pronounced than on the undersides of the leaves (Figures 9-10). Field symptoms produced by citrus leprosis can be confused with feeding damage from other insects, such as stink bug. A similar disease that can be confused with citrus leprosis is zonate chlorosis, which occurs in Brazil but not in Florida, and which is less severe. Zonate chlorosis, the cause of which is unknown, produces larger chlorotic patterns that may cover a large part of affected leaves but do not become necrotic like citrus leprosis.

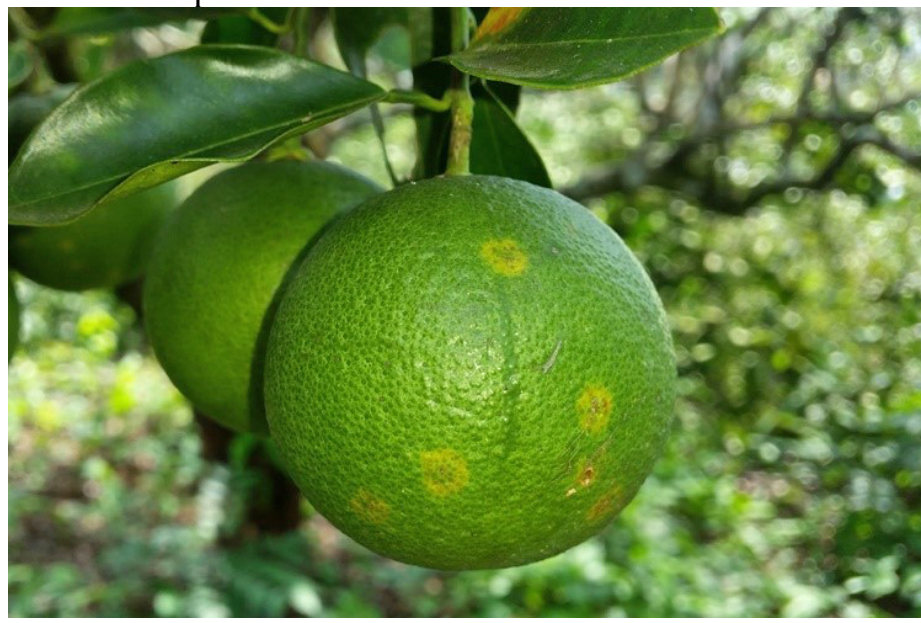

Figure 3. Early symptoms of disease with chlorotic lesions on fruit. Credits: I. Izquierdo, SAGARPA, Mexico

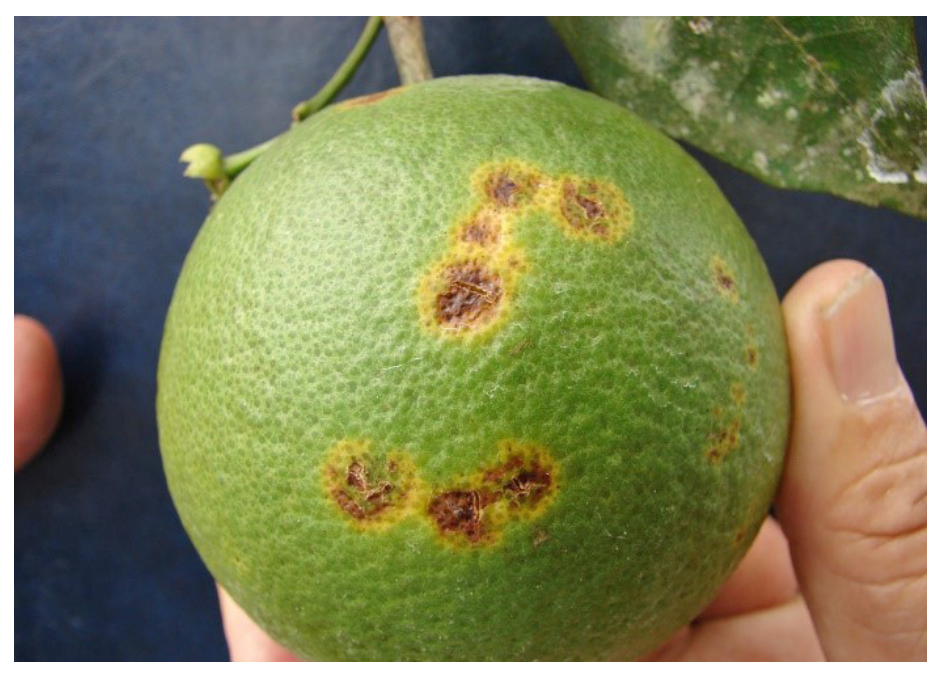

Figure 4. Older lesions showing signs of gumming and cracking, with a distinct yellow halo.

Credits: H. Gomez, USDA 


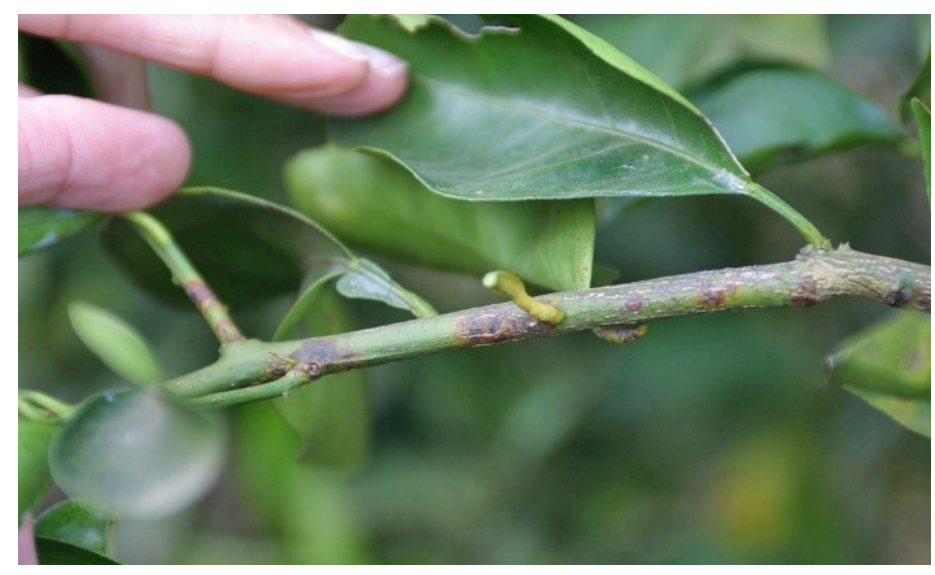

Figure 5. Early-stage, shallow lesions on stem.

Credits: M. Manners, FSC

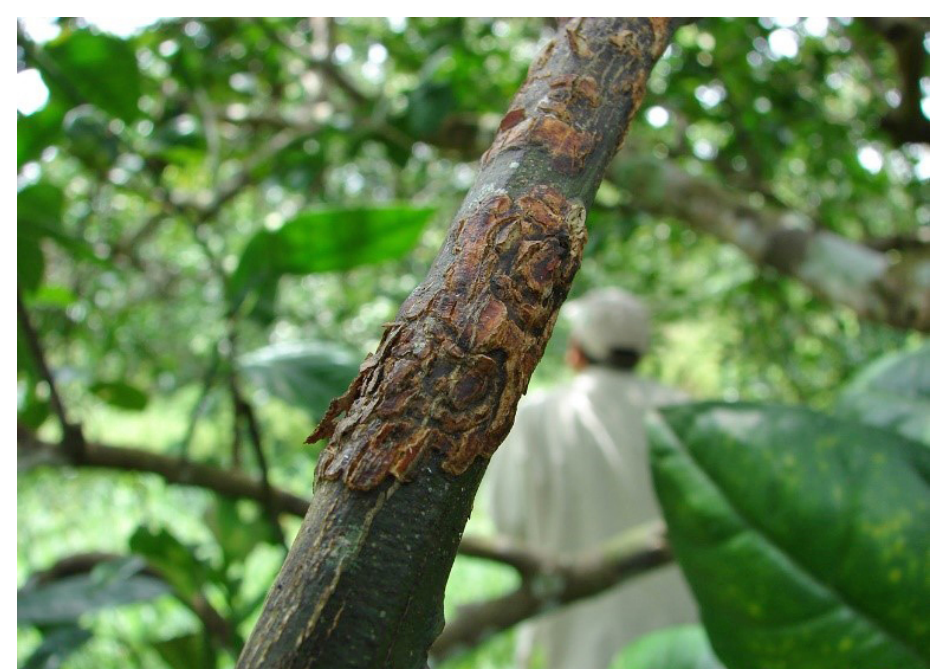

Figure 6. Older lesions, corky and scaly bark.

Credits: H. Gomez, USDA

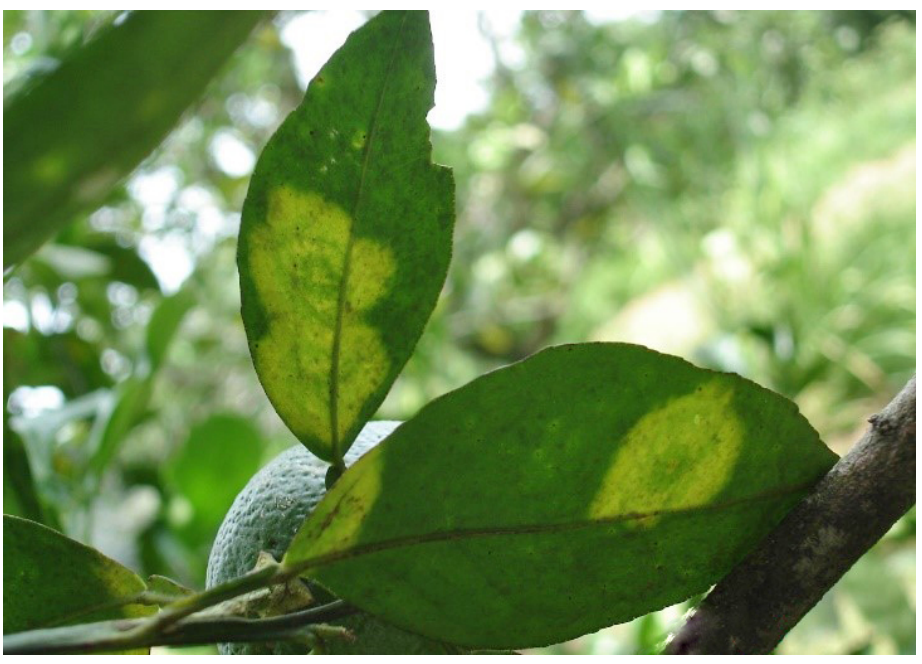

Figure 7. Early chlorotic leaf lesions caused by C-type citrus leprosis viruses.

Credits: B. Reyes, SAGARPA, Mexicp

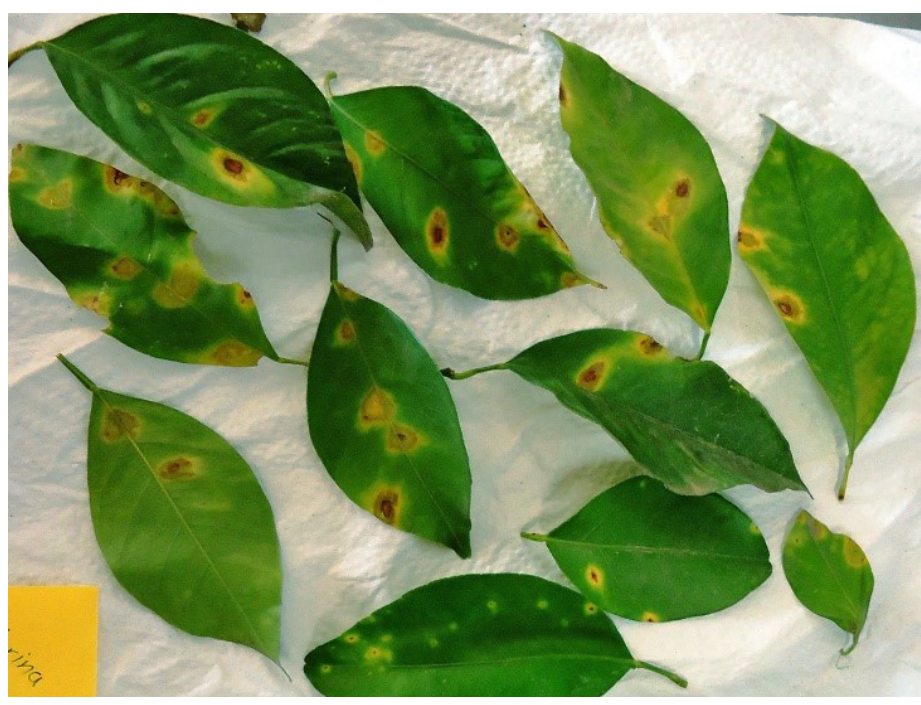

Figure 8. Leaf lesions showing necrotic centers caused by N-type citrus leprosis viruses.

Credits: I. Alanis

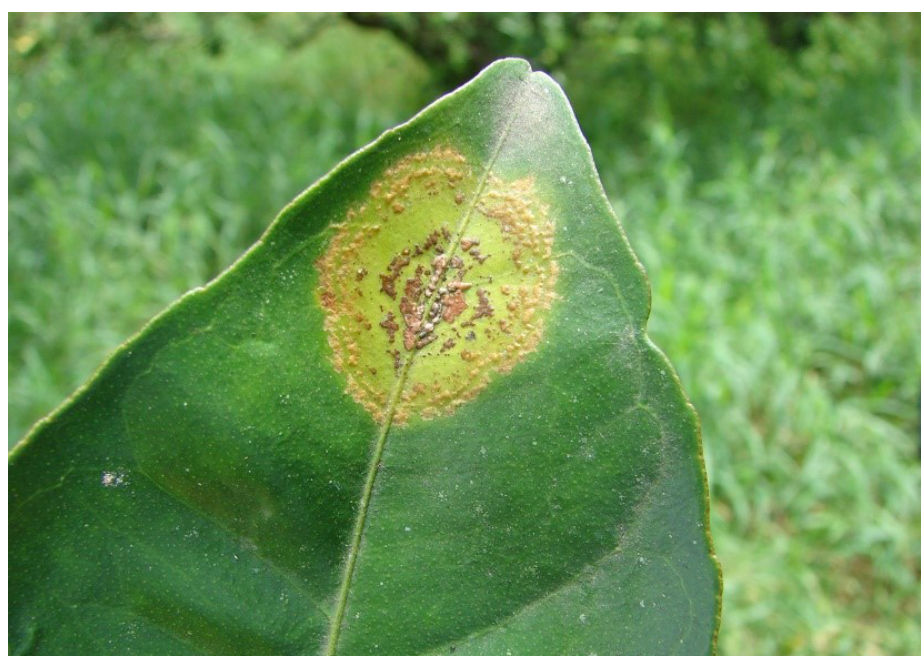

Figure 9. Leaf lesions on the upper side of the leaf (C-type viruses). Credits: H. Gomez, USDA

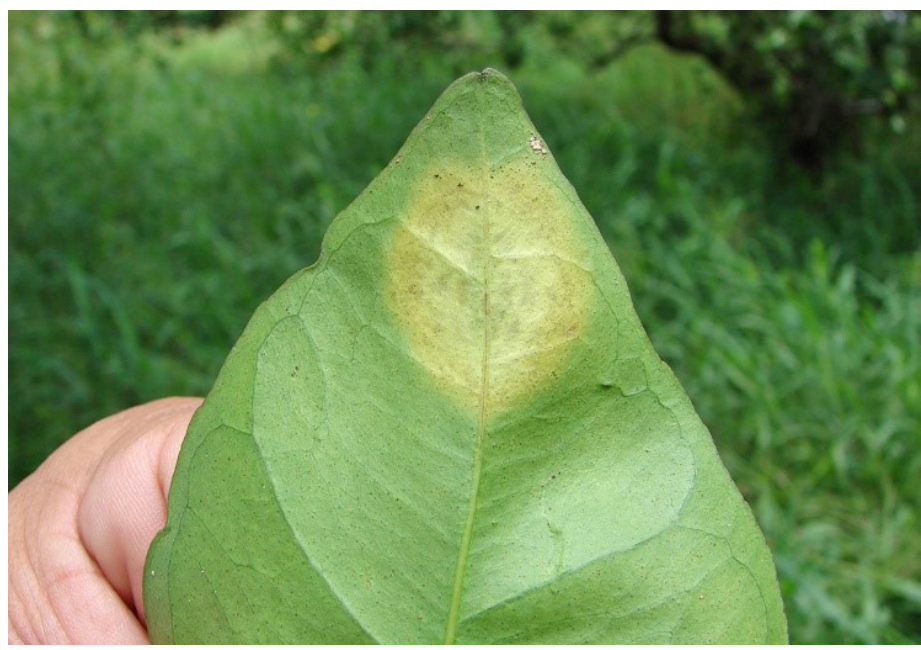

Figure 10. Corresponding leaf lesion on the underside of the leaf, less pronounced (C-type viruses).

Credits: H. Gomez, USDA 


\section{How is citrus leprosis transmitted?}

Citrus leprosis is mainly transmitted by several species of Brevipalpus mites (B. phoenicis, B. californicus, B. obovatus, and B. yothersi) (Figure 2). Citrus leprosis virus replicates inside the mites, and when mites feed on the plant, the virus is transmitted to the tree. Citrus leprosis has been transmitted mechanically from sweet orange to sweet orange, and from sweet orange to several herbaceous hosts, but attempts to transmit the virus from herbaceous plants back to citrus have failed. Citrus leprosis has been very difficult to transmit to citrus by grafting. Transmission occurs by grafting only when symptomatic areas of the inoculum tissue are in contact with the receptor plant. Symptoms develop only in immediately adjacent tissues of the receptor plants. Thus, mites in fields readily transmit citrus leprosis.

\section{How can citrus leprosis be detected and controlled in the field?}

Symptoms of citrus leprosis are easily visible on leaves, fruits, and twigs in the field. Confirmation can be done by electron microscopy of infected tissue to observe bullet-like virus particles for the nuclear type, or short rods for the cytoplasmic type of citrus leprosis viruses. Although local lesions have been observed in mechanically inoculated herbaceous hosts, these are not diagnostic. Diagnosis that is more definitive must be done in the laboratory with molecular analyses such as serological and PCR-based assays. A new multiplex molecular detection technique for citrus leprosis viruses, which can identify five different citrus leprosis viruses in one analysis, was recently developed. Control of mite populations greatly limits the spread and development of citrus leprosis. Windbreaks, removing dropped fruit, and cleaning equipment before moving between fields can limit mite dispersal. Pruning the affected trees may reduce the inoculum sources. A major question is whether there are other natural hosts of the citrus leprosis viruses that could serve as an inoculum source in Florida or whether a reservoir can be maintained indefinitely in mites. As observed in Brazil, well-managed groves are less affected than those receiving minimal care.

\section{What can growers do?}

Given that Florida's climatic conditions are highly suited for establishment of the pathogen, citrus leprosis is predicted to have an economic impact on citrus production in Florida if found again. Preventing citrus leprosis from re-entering Florida is much easier than trying to eradicate or control it. It is important to avoid bringing propagation materials from areas infected with citrus leprosis into Florida. All citrus propagative materials must be introduced by proper procedures through the Florida Department of Agriculture and Consumer Services, Division of Plant Industry. Along with prevention, it is important to educate all personnel in the field about citrus leprosis. Education on symptoms is beneficial for scouting efforts to aid in early detection. If this disease is found early, management practices may be able to mitigate the economic impact from infection. Thus, growers are encouraged to report samples suspected to have citrus leprosis to their citrus pathology specialist or local UF/IFAS Extension agent for diagnosis. Alternatively, growers can request a multi-pest survey in their groves by contacting Citrus Health Response Program Offices in their location (https://www.fdacs.gov/Divisions-Offices/Plant-Industry/ Agriculture-Industry/Citrus-Health-Response-Program/ Citrus-Health-Response-Program-Field-Offices).

\section{Selected References}

Bastianel, M., V. M. Novelli, E. W. Kitajima, K. S. Kubo, R. B. Bassanezi, M. A. Machado, and J. Freitas-Astua. 2010. "Citrus Leprosis: Centenial of an Unusual Mite-Virus Pathosystem.” Plant Dis 94 (3): 284-292.

Bastianel, M., J. A. Pereira-Martin, V. M. Novelli, J. FreitasAstua, and M. A. Nunes. 2018. "Citrus Leprosis Resistance within the Citrus Group." Virus Disease 29 (4): 491-498.

Childers, C. C., J. C. Rodrigues, K. S. Derrick, D. S. Achor, J. V. French, W. C. Welbourn, R. Ochoa, and E. W. Kitajima. 2003. "Citrus Leprosis and Its Status in Florida and Texas: Past and Present." Experimental and Applied Acarology 30:181-202.

Dewdney, M. M., J. D. Burrow, M. E. Rogers, and T. M. Spann. 2015. Exotic Diseases of Citrus. PP264. Gainesville: University of Florida Institute of Food and Agricultural Sciences. https://edis.ifas.ufl.edu/pp264.

Garita, L. C., A. D. Tassi, R. F. Calegario, J. Freitas-Astúa, R. B. Salaroli, G. O. Romao, and E. W. Kitajima. 2014. "Experimental Host Range of Citrus Leprosis Virus C (CiLV-C)." Tropical Plant Pathology 39 (1): 043-055.

Hartung, J. S., R. Ochoa, R. H. Brlansky, A. Roy, J. da Graca, and W. L. Schneider. 2013. "Recovery Plan for Citrus Leprosis." United States Department of Agriculture.

Hartung, J. S., A. Roy, S. Fu, J. Shao, W. L. Schneider, and R. H. Brlansky. 2015. "History and Diversity of Citrus Leprosis 
Virus Recorded in Herbarium Specimens." Phytopathology 105 (9): 1277-1284.

Knorr, L. C. 1968. "Studies on the Etiology of Leprosis in Citrus." In Proceeding 4th Conference International Organization of Citrus Virology, 332-341. Gainesville: University of Florida Press.

Lovisolo, O., A. Colariccio, C. M. Chagas, V. Rossetti, E. W. Kitajima, and R. Harakava. 1996. "Partial Characterization of Citrus Leprosis Virus." In Proceeding 13th Conference International Organization of Citrus Virology, Riverside, CA, 179-188.

Rossetti, V. 1996. "Transmission of Citrus Leprosis Disease-A Review." In Proceeding 13th Conference International Organization of Citrus Virology, Riverside, CA, 331-335.

Roy, A., N. Choudhary, L. M. Guillermo, J. Shao, A. Govindarajulu, D. Achor, G. Wei, D. D. Picton, L. Levy, M. K. Nakhla, J. S. Hartung, and R. H. Brlansky. 2013. "A Novel Virus of the Genus Cilevirus Causing Symptoms Similar to Citrus Leprosis." Phytopathology 103:488-500.

Roy, A., J. S. Hartung, W. L. Schneider, J. Shao, G. Leon, M. J. Melzer, J. J. Beard, G. Otero-Colina, G. R. Bauchan, R. Ochoa, and R. H. Brlansky. 2015. "Role Bending: Complex Relationships between Viruses, Hosts, and Vectors Related to Citrus Leprosis, an Emerging Disease." Phytopathology 105:1013-1025.

Tassi, A. D., L. C. Garita-Salazar, L. Amorim, V. M. Novelli, J. Freitas-Astúa, C. C. Childers, and E. W. Kitajima. 2017. "Virus-Vector Relationship in the Citrus Leprosis Pathosystem." Experimental and Applied Acarology 71 (3): 227-241. 